Available online at: https://proceeding.researchsynergypress.com/index.php/rsfconferenceseries1

RSF Conference Series: Business, Management and Social Sciences

e-ISSN 2807-5803/ p-ISSN 2807-6699

Volume 1Number 4 (2021): 190-201

\title{
Covid-19 Disaster Management through Websites and Social Media Regency/City Government in the Special Region of Yogyakarta
}

\author{
Isbandi Sutrisno', Edwi Arief Sosiawan² \\ 1,2 Faculty of Social and Political Science, UPN “Veteran" Yogyakarta
}

\begin{abstract}
The severity of criticism in handling the COVID-19 pandemic has made local governments turn to information and communication technology to back up various important information in mitigating the handling of COVID-19. Although the district/city government in Yogyakarta has taken advantage of digitalization in the operation of its government system, it is still a question mark whether the district/city local government can utilize websites and social media as a means and media for handling COVID -19 effectively and efficiently mapping COVID-19 data. And socialization of its handling to the community. The research method used is descriptive qualitative research to obtain comprehensive data related to disaster management through websites and social media by the district/city government in Yogyakarta. The results show that the use of websites and social media by the Sleman Regency Government and Yogyakarta City Government to mitigate the COVID-19 pandemic is utilizing online data sources for early detection of disease; in the form of notification of diagnosed cases, data visualization tools for decision support, namely the use of collecting public health data in real-time, as well as the use of public communications related to the mitigation of the covid-19 pandemic. The conclusion obtained is that the use of pages and social media used by the Sleman Regency Government and the Yogyakarta City Government has similarities in their use, both back office and front office. However, there are differences in information content both on the page and social media users.
\end{abstract}

Keywords: Disaster Management, website, social media Introduction

This is an open access article under the CC-BY-NC license

\section{INTRODUCTION}

The coronavirus (COVID-19) pandemic has affected daily life and slowed down various sectors of life globally. This pandemic has affected thousands of people, who got sick or died because of its massive spread. COVID-19 is a new viral disease that attacks humans for the first time with relatively unavailable vaccine prevention. Therefore why then the emphasis on preventing Covid-19 is to focus on taking extensive preventive measures such as implementing health protocols.

The Covid-19 virus is spreading exponentially in terms of regions. Many countries have locked down their populations and imposed strict quarantines (lockdowns) to control the spread of COVID-19. Likewise, hundreds of local government entities have issued policy changes in response to the COVID-19 pandemic. Regional government offices and services are limited or closed, followed by work from home policies, large-scale social restrictions (PSBB) to strict action against crowd violations in public spaces.

Efforts to prevent COVID-19 carried out by local governments are more likely to receive negative responses, such as various public criticisms that have become increasingly harsh since March 2020 due to dire consequences for health, social conditions, and the economy. Research by Suryahadi et al (2020) has identified three structural problems behind ineffective government policies and programmatic responses to Covid-19 which state; First, the distribution of authority is unclear after the Covid-19 outbreak was declared a national 
RSF Conference Series: Business, Management and Social Sciences

Volume 1Number 4 (2021): 190-201

Covid-19 Disaster Management through Websites and Social Media Regency/City Government in the Special Region of Yogyakarta

Isbandi Sutrisno, Edwi Arief Sosiawan

disaster, there was no centralized national effort to control the spread of the virus and manage its impact. Second, efforts to mobilize and utilize strategic resources are still limited. Synchronous use of resources such as databases and government programs is lacking or completely non-existent. Third, the lack of flexibility in responding to policy issues across regions and levels of government.

The severity of the criticisms in handling the COVID-19 pandemic, various local governments tend to turn to information and communication technology to back up various important information in socializing and mitigating the handling of COVID-19. This is because regular updating of accurate and precise information is a necessity for citizens to actively identify 'red zones' areas to protect themselves and assist local governments in planning appropriate actions for public services such as health and education.

Although the district/city government in Yogyakarta has utilized digitalization in the operation of its government system, it is still a big question mark whether the district/city government has also been able to utilize websites and social media as a means and media for handling COVID-19 effectively and efficiently in mapping data. COVID-19 and socialization of its handling to the community along with the simultaneous enforcement of health protocols. This needs to be studied considering that various COVID-19 cases are still emerging in districts and cities in Yogyakarta.

This study tries to read on the other side that is not yet in the handling of COVID-19 carried out by the district/city government in Yogyakarta through the use of the website as an egovernment implementation platform and social media as a new medium for the operation of the local government system. This research also complements previous research that tends to highlight the handling of COVID-19 by local governments through policy systems such as the research of Juaningsih et al (2020) or Wiryawan (2020). Therefore, the formulation of the problem in this study is: "How is the use of websites and social media in COVID-19 disaster management by district and city governments in the Special Region of Yogyakarta Province?". Literature review

Disaster management can be defined as the management of resources and responsibilities for dealing with all aspects of humanity in an emergency, particularly preparedness and recovery organizations to reduce the impact of disasters (Mc Entire, 2000). Disaster management is a shared responsibility between the government, the private sector, and civil society. Partnerships between the government and the private sector are a prerequisite for sustainable and effective disaster management. Likewise, cooperation between government agencies is equally important because of the cross-sectoral nature of disaster management (Sosiawan, 2013).

The paradigm shift in disaster management globally is "awareness" of ending or reducing disasters that began in 1990. Until now, there are 4 phases to the paradigm shift in disaster management, namely: a). The paradigm of relief/emergency response (the 60s); In the relief/emergency response paradigm, disaster management occurs during a disaster event through the provision of emergency assistance in the form of food, shelter, and health. The main objective of the treatment is to overcome the suffering of the victims and repair the damage caused by the disaster and immediately carry out the recovery (recovery). B). Mitigation paradigm (the 80s); In the mitigation paradigm, disaster management focuses on identifying hazards that threaten and individual/community patterns that create vulnerability to disasters. Mitigation or impact on disasters is carried out physically/structurally. In 
RSF Conference Series: Business, Management and Social Sciences

Volume 1Number 4 (2021): 190-201

Covid-19 Disaster Management through Websites and Social Media Regency/City Government in the Special Region of Yogyakarta

Isbandi Sutrisno, Edwi Arief Sosiawan

contrast, mitigation of vulnerable behavior patterns is carried out non-structurally. C). Development paradigm (the 90s); is a disaster management paradigm that focuses on the primary causes and processes of community vulnerability to disasters. D). The reduction paradigm (the 2000s); combines technical and scientific perspectives on social, economic, political, and environmental conditions. Disaster management starts from analyzing disaster analysis based on threats/hazards and vulnerabilities to increase the ability to manage and reduce risks and reduce the impact of disasters. Disaster management is carried out jointly by all stakeholders, across sectors, and community empowerment. (Hidayati, Sri, et al, 2009)

Concerning the use of information and communication technology (ICT) in disaster management, it is in the form of emphasizing the importance of ICT for conducting data collection, data analysis, data management, and data use and delivery of relevant practical information (UNISDR, 2015, 9). ICTs used in disaster management can vary according to the three factors involved in the process, namely 1) the nature of disaster risk: biological, technological, socio-environmental; 2) risk management scale: global, regional, local; 3) management models and stages: circular or square, pre-disaster, trans-disaster or postdisaster (Sagun, 2009). Hence there is an asymmetry in the use of ICTs across different phases of disaster management. While one technology may be more suitable for the pre-disaster stage, another technology may be more ideal for the trans-disaster phase. The most frequently used ICT in the pre-disaster step is to work on the information before communicating it to its users. On the other hand, open architecture mechanisms (social networks and mobile applications) can be more used in the trance and post-disaster phases. They allow the user community to use them to share and generate information.

Concerning the operationalization of ICT in various management phases, it is possible to describe the types and asymmetry of use through differentiation according to (Lindsay 2011) the following: a). Social networks (Facebook, Twitter, WhatsApp, Skype, YouTube) are networks created on the Internet that allow interaction and sharing of information by people with similar interests. The use of social networks in disaster management can be felt in two moments: 1) trans-disaster: used to disseminate information and receive feedback from users through messages received, sent, and shared. 2) post-disaster: use of media to receive requests for help, monitor user activity, and use uploaded information to make damage estimates. b). Alert System: This is a procedure (performed by various instruments). Information about a foreseeable threat is collected and analyzed to alert vulnerable populations in advance of a potentially damaging event. c). Mobile Applications: Applications can be defined as "software applications designed to run on mobile operating systems" (Sung, 2011, p. 03) and are widely used in the trance and post-disaster periods. d). Radio and Television: commonly used in all phases of disaster management (UN, 2010), with high effectiveness for places and people with difficulty accessing technology. Although more efficient in the pre-and post-disaster period, radio is also efficient in trans-disaster as it can maintain communication in disaster-affected areas that do not have electricity and is recommended in emergency equipment. e). Amateur radio has the quality to function when all other means of communication collapse due to the impact of a disaster; in this respect, they are particularly effective in trans-disaster periods. The simple structure and equipment of amateur radio make it more independent of energy and internet infrastructure. This quality of operation using amateur radio becomes paramount reliability when all other means of communication collapse at the disaster (Cardoso et al., 2014). f). Cell phones and text messages (Simple Message Service - SMS): Cell phones have potential in the trance and post-disaster phases. Early warning can be used to organize post- 
RSF Conference Series: Business, Management and Social Sciences

Volume 1Number 4 (2021): 190-201

Covid-19 Disaster Management through Websites and Social Media Regency/City Government in the Special Region of Yogyakarta

Isbandi Sutrisno, Edwi Arief Sosiawan

disaster recovery efforts. On the other hand, SMS is essential, especially in the trans-disaster period, because SMS provides high-capacity messages without disrupting communication.

\section{Research methods}

This study uses a qualitative paradigm to obtain comprehensive data to identify websites and social media in Covid-19 disaster management. This qualitative method uses a descriptive type of research to create a problem picture regarding a situation or event. This type of research only describes facts to answer the formulation of research problems by providing a systematic, factual, and actual description of the attributes, characteristics, and relationships between phenomena to be investigated (Moh Nazir 1985, 64). This analysis consists of three activities streams that coincide: data presentation and conclusion drawing. Qualitative data analysis is an ongoing, iterative, and continuous effort. The problem of data reduction, data presentation, and concluding/verification is a picture of success sequentially as a series of analytical activities that follow each other.

\section{Results and Discussion}

\section{Covid-19 Handling Policy in Sleman Regency}

Sleman Regency is one of the regencies in Yogyakarta that has the first rank with the most Covid-19 cases. Therefore, the Sleman Regency Government in general prepares and implements the handling of Covid-19 in Sleman Regency in a severe and integrated manner. Several factors cause Covid-19 cases in Sleman Regency to tend to be high or soaring, namely, first, the area is only 18 percent of the total area of DIY. Still, the population is 33 percent of the total population in DIY. This level of population density is the leading cause. The consequences of population mobilization are also high, which causes transmission or the opportunity for a spike in cases that tends to increase. Second, the number of visits to Sleman Regency is very high. The population is almost one million one hundred people, but generally, only 250 to 300 thousand have a population of Sleman. This has also led to an increase in the number of Covid19 cases. The many tourist destinations in Sleman Regency also encourage mobility and social contact between migrants and natives to open up opportunities to spread the Covid-19 virus.

The Sleman Regency Government's policy in dealing with the Covid-19 pandemic is by other regional government standards, namely forming a Covid-19 task force to stabilize further and strengthen coordination in handling the Covid-19 pandemic disaster. The formation of the task force was based on the Decree of the Sleman Regent Number 19.2/Kep.KDH/A/2020 concerning the Task Force for Handling the Corona Virus Disease 2019 (COVID-19) Sleman Regency. To increase vigilance and handling of COVID-19 in addition to the formation of a Task Force, the Sleman Regency Government has also issued Regent Instruction Number 443/0021 dated March 17, 2020, concerning Increased Awareness and Handling of the Risk of Transmission of COVID-19 Infection.

The task force formed by the Sleman Regency Government consists of directors and implementers. The directors are the Sleman Regent as chairman, and the deputy chairman consists of the Deputy Regent, the Police Chief, and the Sleman Dandim. Meanwhile, the implementers cover health, education, economics, social, operational, communication, and information. The coordinators of each field can be detailed as follows: health by the head of the Health Service, education by the director of the Education Office, economics by the director of the Tourism Office, social affairs by the head of the Social Service, operations by the head of BPBD executive, communication and information by the head of the Kominfo Service. 
RSF Conference Series: Business, Management and Social Sciences

Volume 1Number 4 (2021): 190-201

Covid-19 Disaster Management through Websites and Social Media Regency/City Government in the Special Region of Yogyakarta

Isbandi Sutrisno, Edwi Arief Sosiawan

Besides forming a task force, the Sleman Regency Government also carries out education and literacy for the community in Sleman Regency. One way to educate the public in dealing with the Covid-19 pandemic is to use the slogan Cita Mas Jajar to remind Sleman residents always to remember and comply with the Covid-19 prevention Health Protocol. Cita Mas Jajar uses three approaches consisting of: a). Washing Hands with Soap (CTPS) or hand sanitizer; namely the recommendation that the hands should not be used as a medium for the transfer of disease because the hands are used to hold objects whose cleanliness is often not known with certainty. b). Wearing a Mask; The appeal for the use of masks is part of a comprehensive series of prevention and control measures that can limit the spread of certain respiratory viral diseases, including Covid-19. c). Keep a minimum distance of 1.5 meters; invites to maintain physical distance or physical distancing is the limitation of physical distance between humans, which is different from social distancing. Physical Distancing is just physical distancing and doesn't mean breaking kinship or social ties.

The following policy is that the Covid-19 protocol conditions public services at every level. Circulars to comply with the Covid-19 protocol are disseminated in stages and even accompanied by simulations when opening public services. Regarding public service policies during the Covid-19 pandemic, the Sleman Regency Government combined an integrated online system by significantly optimizing the Sleman Smart Regency policy implementation. These services must be a combination of regulatory systems, policies, attitudes, and behaviors supported by modern information technology. To provide high response and effectiveness according to the needs of the community during the Covid-19 pandemic.

On the one hand, people who need public services are also trained and involved in simulating information communication technology (ICT) to adapt to various public services, including tourism, trade, culinary, services, hotels, restaurants. Through this simulation, it is hoped that the people of Sleman Regency can understand the impact when they do not comply with health protocols and avoid being exposed to Covid-19.

The policy is tripartite, namely one the government facilitates so that the community is guaranteed public services. Second, the people who are certified when carrying out activities, there are guarantees from the government. Third, migrants from outside Sleman Regency must understand and need to receive socialization of the health protocol in Sleman, along with the rules in it.

\section{Utilization of pages and social media in handling Covid-19 in Sleman Regency}

The website used by the Sleman Regency Government that contains information about the handling and development of data on the Covid-19 outbreak is located at corona.slemankab.go.id. This page is used to monitor the development of victims of the Covid19 virus, which includes the need for data collection, providing information, distributing verified publications, and preventing hoax news in the community. In its development, the page is used to trace and track the spread of Covid-19. Therefore, it is very clear that the corona.slemankab.go.id page was created. It aims to utilize information and communication technology for prevention and treatment, utilization of infrastructure and resources, and providing information and education to the public about steps to minimize the spread of the coronavirus.

Regarding using the website to assist handling of Covid-19 by the Sleman Regency Government, it is also in line with the Smart City Masterplan (Smart City) policy for Sleman Regency as one of 25 Regencies/Cities participating in the movement towards 100 Smart Cities 
RSF Conference Series: Business, Management and Social Sciences

Volume 1Number 4 (2021): 190-201

Covid-19 Disaster Management through Websites and Social Media Regency/City Government in the Special Region of Yogyakarta

Isbandi Sutrisno, Edwi Arief Sosiawan

in Indonesia. As one of the Smart Cities, the Sleman Regency Government has integrated the development of the Sleman Regency to achieve an elegant regency based on the optimization of various things. (Interview with the Head of the Sleman Regency Communications and Information Office Eka Suryo Prihantoro, 24/6/2021).

The logic of the connection between the use of websites and social media and the handling of Covid-19 can be seen in the principles of mobile-first, system and data-driven technology, and digital experience. The focus of mobile-first is access to data and information related to Covid-19 through various platforms, including smartphones. The phenomenon of today's society can not be separated from smartphones. The mobile-first principle is closely related to the use of smartphones which are important media that will always be carried and cannot be separated from the grasp of ordinary people. Through the corona.slemankab.go.id page, can simplify all the needs of the community regarding the availability of solutions and information on the Covid-19 pandemic with the menu provided and interactive facilities.

The second principle, System and Data-Driven Technology, is transparent access to the latest Covid-19 data. Getting valid and up-to-date data related to Covid-19 is vital for the community. Through the principle of system and data-driven technology, the people of Sleman Regency will find it easier to obtain transparent data and information. System and data-driven technology help integrate, collect, process, and visualize Covid-19 data. This facility is not only beneficial for the wider community. Easy access to data can also help stakeholders or stakeholders to design and take appropriate policies in dealing with Covid-19. The corona.slemankab.go.id page is a concrete product of the principle of system and data-driven technology because it can be used to check the development of the number of Covid-19 cases, monitor case distribution maps, check the availability of beds at referral hospitals, to monitor the distribution of social assistance.

The third principle of Digital Xperience, namely the handling of covid-19 through increasing digital literacy. The development of technology and digital transformation must, of course, be accompanied by higher digital literacy. Therefore, corona.slemankab.go.id can work together with many parties to improve digital literacy among the community. One of the digital experience products is a menu infographic. The people of Sleman Regency can conduct an independent assessment to test the symptoms of Covid-19 more quickly and easily, without the need to meet with a doctor physically.

The management of the corona.slemankab.go.id page is carried out by the Sleman Regency Communication and Information Office (Kominfo) as part of the Sleman Regency Covid-19 task force. However, in disseminating information or content broadly with other fields, namely health by the Health Office, education by the Education Office, economics by the Tourism Office, Social Community by the Social Service, operations by the Regional Disaster Management Agency (BPBD).

The back office management of the corona.slemankab.go.id page is carried out by the Communications and Information Office of Sleman Regency, which is carried out by the eGovernment and Encryption Service Division which has the main task of developing and managing applications, and integrating information systems as well as developing and executing government applications, public services. And business services. The Public Relations Section assists this field in coordination with the Regional Apparatus Service and Organizations (OPD), who participate in presenting the information on the main page. One of the main OPDs in question is the website management team of the Sleman District Health Office, which the Head of the Planning Sub-Section chairs. 
RSF Conference Series: Business, Management and Social Sciences

Volume 1Number 4 (2021): 190-201

Covid-19 Disaster Management through Websites and Social Media Regency/City Government in the Special Region of Yogyakarta

Isbandi Sutrisno, Edwi Arief Sosiawan

When viewed from the front office, the corona.slemankab.go.id page does not use animation techniques at all, but only in the form of several menus with illustrated images and icons as well as infographics. The corona.slemankab.go.id design page is quite simple, not luxurious with a white background like the background on other OPD pages. The corona.slemankab.go.id page only provides one version, namely the Indonesian version. The design does not use frames, meaning that links transferred to other links directly use words, icons, and graphics.

The content presented on the corona.slemankab.go.id page is explained in several information links, a). The main menu consists of; home, data, releases, self-detection, schedule, contacts, help reports, and searches. Each menu has the following information functions; The home menu shows the main page and contains infographics about the latest information on the development of handling and conditions of the Covid-19 case in Sleman district. The infographic is made to make it easier for users of the corona.slemankab.go.id page to get the latest info and carry out anti-spreading against the covid-19 pandemic that is developing in Sleman Regency.

For other menus, namely the data menu, which contains the Covid-19 Information dashboard, the Development of Covid-19 Cases, the Development of Homecomers / Immigrants, the Distribution of Patients per District, and the Distribution of Homecomers per District. Meanwhile, the release menu contains News, Infographics, Public Documents, and Hoax Info. The self-detection menu includes service info to independently check whether a person has COVID-19 or not for civil servants and the general public. The agenda menu contains the schedule for the Covid-19 task force in carrying out spraying and other activities to mitigate COVID-19. In contrast, the assistance menu contains telephone numbers that can be contacted for information related to COVID-19 in Sleman Regency. The report menu includes reports on the realization of receipts and expenditures of donated goods from the public per month; search is a menu for searching for information data needed by the people using the corona.slemankab.go.id page.

In addition to using the corona.slemankab.go.id page in conveying information to the public, social media is also used as a means of mitigating the covid-19 pandemic. The social media are Facebook and Instagram, which the Sleman District Health Office manages. In addition to social media, the Sleman District Health Office also uses a particular page to socialize the handling of Covid-19, namely Search and Control Covid-19 Problems in the form of infographics and information links related to the socialization and internalization of general information for public literacy in preventing covid-19 such as the Habit Adaptation e-flyer. New (IMR) from the Indonesian Ministry of Health and the Covid-19 Protocol.

For the use of Facebook with the address https://www.facebook.com/diskominfo.sleman, the Sleman District Health Office uses it as additional information because the information content related to COVID-19 is an insert between general and institutional information posts. Meanwhile, the @dinkessleman account is used more to deliver information related to the handling and prevention of the covid-19 pandemic in the form of posters or flyers according to Instagram's characteristics that prioritize visual content. In addition, the @dinkessleman account is also used to convey information data related to COVID-19 case data and its development in Sleman Regency.

\section{Policies for Handling Covid-19 in Yogyakarta Municipality}


RSF Conference Series: Business, Management and Social Sciences

Volume 1Number 4 (2021): 190-201

Covid-19 Disaster Management through Websites and Social Media Regency/City Government in the Special Region of Yogyakarta

Isbandi Sutrisno, Edwi Arief Sosiawan

The approach in handling COVID-19 in the Yogyakarta City Government (Pemkot) is to use the principles of being fast, precise, synergistic, and integrated between all institutions. Therefore, in its implementation, cooperation is carried out between all OPDs in the Yogyakarta City Government and the community to deal with Covid-19. The Yogyakarta City Government has a vision that by inviting the community to participate in handling the COVID19 disaster, it will be easier to overcome and the community can adapt to existing conditions while at the same time finding their way to rise from their condition. The handling of COVID-19 in Yogyakarta is guided by the Mayor's Regulation (PERWALI) Yogyakarta City Number 51 of 2020 concerning Mayor Regulations (PERWALI) concerning Guidelines for the Prevention and Control of Corona Virus Disease-19.

The Yogyakarta City Government has also taken several steps in handling COVID-19, one of which is the reallocation of the budget. The existence of the covid-19 pandemic caused the budget that had been set in 2019 to be reworked to then be optimized for the implementation of the COVID-19 pandemic mitigation. The unexpected expenditure budget that has been allocated is intended for health care, both from unexpected costs and from the APBD.

The Yogyakarta City Government has also implemented crisis management by ordering all OPDs to focus on recovering from Covid-19. This method is carried out by the Yogyakarta City Government so that the entire budget for planning, programs and activities that have been determined is allocated for handling Covid-19. Other policies are carried out with cross-sectoral collaboration such as corporations, communities, campuses, and villages for the handling of COVID-19. This policy is called the Gandeng Gendong program, which is the empowerment of the people of the City of Yogyakarta to work together and work together to face the crisis period during the COVID-19 pandemic. Empowerment carried out with the community is to help residents in their environment who are affected by COVID-19. Meanwhile, corporate empowerment is carried out to overcome the economic impact of the poor by involving them in their economic activities.

In general, the Yogyakarta City Government has set five stages towards normal conditions. The five stages include a). stages of handling cases of pandemic victims, b). the stages of making new rules or protocols in the form of making health regulations and protocols that touch all aspects of society, c). the stage of conducting trials and limited and gradual implementation in the form of implementing rules and concessions in community activities, d). Jogja's steps for Jogja are in the form of implementing the Gandeng Gendong program so that the people of the city of Yogyakarta work together and work together to face the crisis period during the covid-19 pandemic, and e). the last stage of Jogja for all, namely the Yogya City Government in collaboration with online transportation providers to increase sales in traditional markets and MSMEs in the city of Yogyakarta. In addition, the Yogyakarta City Government has also prepared an economic recovery strategy which is divided into several strengthening points. Starting from strengthening the application of health protocols, strengthening the real economy of the community in the fields of tourism, culture, and Small and Medium Enterprises (UMKM)).

The primary strategy for handling the COVID-19 pandemic by the Yogyakarta City Government is to establish a Covid-19 task force through the Yogyakarta Mayor's Decree Number 65 of 2021 concerning the Establishment of the Yogyakarta City Corona Virus Disease 2019 (Covid-19) Task Force. The Covid, 19 Task Force in the City of Yogyakarta, is chaired directly by the Mayor of Yogyakarta, who is assisted by the Regional Secretary as a secretary 
RSF Conference Series: Business, Management and Social Sciences

Volume 1Number 4 (2021): 190-201

Covid-19 Disaster Management through Websites and Social Media Regency/City Government in the Special Region of Yogyakarta

Isbandi Sutrisno, Edwi Arief Sosiawan

with the implementing elements of the Prevention Task Force with the coordinator of the Assistant for Government and People's Welfare, Public Communication and Behavior Change carried out by the Head of the Communication, Information and Encryption Service, Enforcement Sector. Law and Discipline by the Head of the Civil Service Police Unit. The Coordinator for Handling Tasks is the Assistant for General Administration, the Data and Information Sector is carried out by the Head of the Regional Development Planning Agency, the Health Handling Sector by the Head of the Health Service, the Volunteer Division by the Head of the Governance Section, and the Economic Recovery Sector by the Economic Assistant.

\section{Utilization of websites and social media in handling Covid-19 in Yogyakarta Municipality}

The use of websites and social media by the Yogyakarta City Government for COVID-19 mitigation has similarities with Sleman Regency, namely that it is part of the implementation of the Jogja Smart Service (JSS), which has several services that have been integrated with all related SKPD. Availability of services in JSS applications has several categories; Emergency, Information and Complaints, and General Services. The page used for handling COVID-19 is through the https://corona.jogjakota.go.id/ page, integrated with the Population Service, Disaster Task Force, Health Service, and Education Office.

To assist in handling Covid-19 activities, the Yogyakarta City Government also provides access to communication and information technology (ICT) facilities in the form of trying to expand public access to the internet by increasing accessible wifi locations in public spaces, which reach 211 points spread over 183 RWs and 28 public areas. Open. The consequence is that by providing accessible wifi facilities and ICT access, the Yogyakarta City Government continues to carry out education and literacy so that the people of Yogyakarta can avoid the adverse effects of using ICT while at home due to the COVID-19 pandemic. This activity is a form of the Yogyakarta City Government's efforts towards using the internet by the community. It is hoped that with the sophistication of the internet, all people in the city of Yogyakarta can connect without being constrained by distance and get various benefits by using the internet while reducing activities outside the home. In addition, the provision of accessible wifi facilities aims to suppress the spread of the Covid-19 virus in Yogyakarta through health gadgets and the internet in the community to anticipate the gathering of residents.

The back office for managing the https://corona.jogjakota.go.id/ page as a source of information on handling COVID-19 is fully implemented by the Yogyakarta City Communication, Information and Encryption Service (Kominfosan), which has the main task of helping the Mayor carry out government affairs and assigning privileges. The field of communication and informatics, the area of coding, and a lot of statistics. However, the main task is in the Kominfosan of Yogyakarta, managing the content of the https://corona.jogjakota.go.id/ page in collaboration with other OPDs in content management, especially related parties such as the Health Officer and the Regional Disaster Management Agency (BPBD) of the city of Yogyakarta.

The https://corona.jogjakota.go.id/ page is a simple page without frames and does not use animation techniques for the front office. However, the page design is only in the form of a few menus with illustrated images and icons and infographics. The method of the https://corona.jogjakota.go.id/ page uses an information splitter that changes its content on the home page and uses infographics and text as the content. Despite the simple design, it 
RSF Conference Series: Business, Management and Social Sciences

Volume 1Number 4 (2021): 190-201

Covid-19 Disaster Management through Websites and Social Media Regency/City Government in the Special Region of Yogyakarta

Isbandi Sutrisno, Edwi Arief Sosiawan

provides a vaccination status check facility similar to the care-protect application. Identical to corona.slemankab.go.id the https://corona.jogjakota.go.id/ page only provides one Indonesian version. It is moving from link to link using graphic symbols and photos provided on the home page.

The menu on the https://corona.jogjakota.go.id/ page does not have a submenu, so there are no other link categories in the menu. The available menu consists of a). Home; contains a link to the main home page, which consists of information on the Covid 19 Hotline in the City of Yogyakarta, Check Vaccination Status, Information on the Development of Covid-19 in the City of Yogyakarta, as well as a news column related to the activities of the Yogyakarta City Government in dealing with the COVID-19 pandemic. 19. b). Must know, which contains information related to literacy associated with the Covid-19 situation, such as how to handle if exposed to COVID-19, seek correct information, and reduce risk. c). Latest Info is a menu that refers to lead in the form of news related to the actions and prevention of COVID-19, which is related to the community's needs, d). Find out; is a menu that contains general information about the covid-19 virus, e). The map includes an overview of the current state of COVID-19 in 14 sub-districts of the city of Yogyakarta. Another menu on the https://corona.jogjakota.go.id/ page is the Self Screening menu in the form of detecting yourself whether you are exposed to Covid-19 or not. The following additional menu is Entrant Reports, a menu used as a report regarding the status of immigrants from outside the city of Yogyakarta or residents traveling from outside the city. Meanwhile, the last menu for Independent Monitoring is used to monitor community members who such as runny nose/sore throat/cough and no other cause based on the expected clinical picture and in the last 14 days before the onset of symptoms had a history of traveling or living in an area with local transmission.

In addition to using https://corona.jogja OPD page to disseminate information to the public related to the handling of COVID-19 in the City of Yogyakarta. The Yogyakarta City Health Office uses the https://kesehatan.jogjakota.go.id/ page, which primarily uses the front page to convey news COVID-19. The content of this information tends to be the same as the information contained on the https://corona.jogjakota.go.id/ page and does not have a special menu related to the activities of handling the covid-19 pandemic. Certain information about COVID-19 is made in the form of a slider located on the Yogyakarta City Government Health Office page.

The social media used is Instagram @pemkotjogja, but the content in Instagram $@$ @emkotjogja does not contain specific information about the mitigation of the covid-19 pandemic. Still, it is mixed with general information and other Yogyakarta City Government activities in the form of infographics. The dominant infographic uploaded to @pemkotjogja is an infographic on the daily report of covid-19 or the number of covid-19 sufferers in Yogyakarta. Content that is constantly updated regarding information regarding the COVID-19 pandemic mitigation is carried out through Twitter social media @ Pemkotjogja, which changes every day and has an hour gap in information related to the development of Covid-19 cases in the city of Yogyakarta. In addition to information pertaining to the development of issues, there is also information related to vaccinations and the prevention to control COVID19. Another social media used is Facebook media with an account https://www.facebook.com/humaskotajogja/; the content of social media here is also general, although it is dominated by information on snacks and the development of Covid-19 cases in the city of Yogyakarta and does not use Facebook. As a particular medium for mitigating the COVID-19 pandemic. 
RSF Conference Series: Business, Management and Social Sciences

Volume 1Number 4 (2021): 190-201

Covid-19 Disaster Management through Websites and Social Media Regency/City Government in the Special Region of Yogyakarta

Isbandi Sutrisno, Edwi Arief Sosiawan

The description above shows that controlling the outbreak of the Covid-19 infectious disease is important because it threatens the health of the wider community. Through consideration of the prevention/mitigation phase, preparedness, and response to demonstrate the use of information and communication technology in the emergency management phase, it is possible to analyze the similarities and differences between the Sleman Regency Government and the Yogyakarta City Government in the activities of handling the COVID-19 pandemic through websites and social media. The communication information technology applied by the Sleman Regency Government and the Yogyakarta City Government in several aspects of managing the COVID-19 does not have a significant difference in the use of websites and social media. However, in some aspects, there is a different emphasis on each content delivered.

The use of websites and social media in handling covid-19 by the Sleman Regency Government and Yogyakarta City Government includes a). The online data source for early disease detection; notification of diagnosed cases or can be referred to as syndromic surveillance. Network surveillance is based on clinical symptom reports from selected and primary hospitals and health facilities. The content included in the utilization of these data sources consists of the display of data from online news sites, news aggregation services, social networks, and searches from the web. B). Data visualization tools for decision support; Dashboard data is used to collect real-time public health data, such as death rates and case statistics, to provide information to the public and assist the COVID-19 task force in making policies. C). Public communication; Online data and social media content have an important continuing role in public communication regarding the mitigation of the COVID-19 pandemic. Content on the website and social media also supports compliance with the Covid-19 Task Force policies and the realized steps. Information online on websites and social media can also mobilize the community to comply with various policies made in dealing with COVID-19 and provide ways to help people in need.

\section{Conclusion}

There are similarities in websites and social media used by the Sleman Regency Government and the Yogyakarta City Government, which have similarities in their service to prevent COVID-19. The visible difference is in the content delivered both on the page, and the social media used, each of which has advantages and disadvantages in the completeness of the content delivered. Compared with other districts in Yogyakarta Province, the Sleman Regency Government and Yogyakarta City Government are completely using websites and social media to mitigate the COVID-19 pandemic. From the back office side, the authorized OPD carries page content management and has duties and functions in communication and information technology. In contrast, social media is carried out by each OPD, namely the District and City Government Health and Public Relations Offices.

\section{Reference}

Cardoso, D .; Santos, G. S. P .; Rezende, M. S. C .; Bello, J. Da S. A .; Franzoni, A. M. B, 2014, Knowledge management in responding to natural disasters: the experience of civil defense in the State of Santa Catarina. Perspectives in Management \& Knowledge, João Pessoa, v. 4, n. 2, p. 90-106, 2014 
RSF Conference Series: Business, Management and Social Sciences

Volume 1Number 4 (2021): 190-201

Covid-19 Disaster Management through Websites and Social Media Regency/City Government in the Special Region of Yogyakarta

Isbandi Sutrisno, Edwi Arief Sosiawan

Hidayati, Sri dkk. 2009. Modul Pelatihan Pengintegrasian Pengurangan Risiko Bencana(PRB) ke dalam Sistem Pendidikan. Pusat Kurikulum Badan Penelitian danPengembangan Kriteria Pendidikan Nasional. Jakarta

Juaningsih, Imas Novita, Yoshua Consuello, Ahmad Tarmidzi, Dzakwan NurIrfan, 2020, Optimalisasi Kebijakan Pemerintah dalam penanganan Covid-19 terhadap Masyarakat Indonesia, Salam: Jurnal Sosial dan Budaya Syari, Vol 7 No 11 tahun 2020

Koehler, G.A., G.G. Kress and R.L. Miller. 2001. What Disaster Response Management Can Learn From Chaos Theory. Pp. 293-308 in Farazmand, A. (ed.) Handbook of Crisis and Emergency Management. Marcel Dekker, Inc.: New York.

Lindsay, B. R. 2011,Social Media and Disasters: Current Uses, Future Options and Policy Considerations. Congressional Research Service Reports, 2011. p.1-10

McEntire, D.A. 2000. Sustainability or Invulnerable Development: Justification for a Modified Disaster Reduction Concept and Policy Guide. Ph.D. Dissertation. University of Denver: Denver, Colorado.

Sagun, A.; Bouchlaghem, D.; Anumba, C. J. A, 2009, Scenario-Based Study On Information Flow And Collaboration Patterns In Disaster Management. Disasters, London, v. 33, n. 2, p.214-238, 2009

Sosiawan, Edwi Arief s, Susilastuti DN, Arif Rianto, BN, 2013, Model Manajemen Teknologi Komunikasi Dalam Pemerintahan dan Penanganan Bencana Alam, Jurnal Ilmu Komunikasi UPNVY, Vol 11 No 1, p.1-16

Suryahadi, Asep, Ridho Al Izzati , Daniel Suryadarma, 2020, The Impact of COVID-19 Outbreak on Poverty: An Estimation for Indonesia, Smeru Working Paper th 2020

Sung, S. J. 2011, How can we use mobile apps for disaster communications in Taiwan: Problems and possible practice. In: 8th International Telecommunications Society (ITS) AsiaPacific Regional Conference. p. 1-15

UNISDR (United Nations Office for Disaster Risk Reduction), 2015, Disasters in numbers, United Nation

Wiryawan, I Wayan, 2020, Kebijakan Pemerintah Dalam Penanganan Pandemi Virus Corona Disease 2019 (Covid-19) Di Indonesia, Prosiding Webinar Nasional Universitas Mahasaraswati Denpasar 2020 